\title{
The XPB and XPD DNA helicases are components of the p53-mediated apoptosis pathway
}

\author{
Xin Wei Wang, ${ }^{1}$ Wim Vermeulen, ${ }^{2}$ Jill D. Coursen, ${ }^{1}$ Michael Gibson, ${ }^{1}$ Shawn E. Lupold, ${ }^{1}$ \\ Kathleen Forrester, ${ }^{1}$ Guowei Xu ${ }^{1}{ }^{2}$ Lynne Elmore, ${ }^{1}$ Heidi Yeh, ${ }^{1}$ Jan H.J. Hoeijmakers, ${ }^{2}$ and \\ Curtis C. Harris ${ }^{1,3}$ \\ ${ }^{1}$ Laboratory of Human Carcinogenesis, National Cancer Institute, National Institutes of Health, Bethesda, Maryland \\ 20892-4255 USA; ${ }^{2}$ Department of Cell Biology and Genetics, Medical Genetics Center, Erasmus University Rotterdam, 3000 \\ DR Rotterdam, The Netherlands
}

The molecular pathway of p53-dependent apoptosis (programmed cell death) is poorly understood. Because p53 binds to the basal transcription-repair complex TFIIH and modulates its DNA helicase activities, we hypothesized that TFIIH DNA helicases XPB and XPD are members of the p53-mediated apoptotic pathway. Whereas transfer of a wild-type p53 expression vector by microinjection or retroviral infection into primary normal human fibroblasts resulted in apoptosis, primary fibroblasts from individuals with xeroderma pigmentosum (XP), who are deficient in DNA repair and have germ-line mutations in the $X P B$ or $X P D$ gene, but not in the XPA or XPC gene, have a deficiency in the apoptotic response. This deficiency can be rescued by transferring the wild-type $X P B$ or $X P D$ gene into the corresponding mutant cells. XP-D lymphocytes also have a decreased apoptotic response to DNA damage by adriamycin, indicating a physiologically relevant deficiency. The XP-B or XP-D mutant cells undergo a normal apoptotic response when microinjected with the Ich-1 $L_{L}$ and $I C E$ genes. Analyses of p53 mutants and the effects of microinjected anti-p53 antibody, Pab421, indicate that the carboxyl terminus of p53 may be required for apoptosis. Direct microinjection of the p53 carboxy-terminal-derived peptide (amino acid residues 319-393) resulted in apoptosis of primary normal human fibroblasts. These results disclose a novel pathway of p53-induced apoptosis.

[Key Words: p53; TFIIH; XPB; XPD; apoptosis]

Received January 17, 1996; revised version accepted April 8, 1996.

The tumor suppressor gene product p53 safeguards the genomic integrity of mammalian cells (Lane 1992), by monitoring the $\mathrm{G}_{1}$ checkpoint (Kastan et al. 1992), sensing DNA damage (Lee et al. 1995), assembling the DNArepair machinery (X.W. Wang et al. 1995b), modulating gene amplification (Livingstone et al. 1992; Yin et al. 1992), or activating the cell death program (apoptosis) to remove damaged cells (Yonish-Rouach et al. 1991; Shaw et al. 1992). Apoptosis is a morphologically defined process that plays an important role in maintaining tissue homeostasis (Kerr et al. 1972). The ability of p53 to induce apoptosis has been increasingly recognized as being important for its tumor suppressor function (YonishRouach et al. 1991; Clarke et al. 1993; Lowe et al. 1993b; Symonds et al. 1994; Graeber et al. 1996). Loss of wildtype p53 function, for example, by mutation (for review, see Hollstein et al. 1991; Levine et al. 1991; Greenblatt et al. 1994), decreases cellular apoptosis induced by environmental and therapeutic agents that cause DNA

${ }^{3}$ Corresponding author. damage (Lee and Bernstein 1993; Lowe et al. 1993a,b, 1994). Inactivation of p53 function through mutation, therefore, may provide a selective advantage for clonal expansion of preneoplastic and neoplastic cells. Identification of the mechanism(s) underlying the p53-mediated apoptotic pathway may improve our understanding of the etiology, diagnosis, prognosis, and therapy of human cancer.

The precise mechanism/s $)$ for the induction of apoptosis by p53 is unclear, although several activities of p53 have been identified, for example, transcriptional transactivator, that could participate in this process. The protein can be physically and functionally divided into four domains. These include an acidic transcriptional transactivation domain at the amino terminus (Fields and Jang 1990; Kern et al. 1991; Funk et al. 1992; Lin et al. 1994), a sequence-specific DNA-binding domain at the hydrophobic center portion of the protein /Cho et al. 1994; Pietenpol et al. 1994), a region near the carboxyl terminus containing a tetramerization domain that may be needed for the stabilization of DNA-binding activity (Sturzbecher et al. 1992), and an extreme carboxy-termi- 
nal domain (CTD) containing a regulatory element involved in sequence-specific DNA binding (Foord et al. 1991; Hupp et al. 1992; Bayle et al. 1995; Jayaraman and Prives 1995; Wolkowicz et al. 1995). The CTD has been shown to contribute to nonspecific nucleic acid binding (Foord et al. 1991; Bakalkin et al. 1994) as well as modulation of its transcriptional trans-activation activity (Hupp et al. 1992; Jayaraman and Prives 1995). This region can also be phosphorylated by several kinases including protein kinase $\mathrm{C}$ and casein kinase II (Meek et al. 1990; Hupp and Lane 1994; Takenaka et al. 1995). Deletion or phosphorylation of this region leads to activation of the p53 sequence-specific DNA-binding activity needed for its transcriptional trans-activator function (Hupp et al. 1992; Hupp and Lane 1994). Several genes that are important in the modulation of the cell cycle and apoptosis have been shown to be activated by $\mathrm{p} 53$, including $p 21^{\text {WAF1 }}$ (El-Deiry et al. 1993), GADD45 (Kastan et al. 1992), mdm2 (Perry et al. 1993), cyclin G (Okamoto and Beach 1994), and Bax (Miyashita and Reed 1995) through p53 binding to promoters or regulatory regions containing p53 consensus binding sites. Other genes important in the regulation of apoptosis including Fas and Bcl-2 also can be regulated positively or negatively by wild-type p53 (Miyashita et al. 1994; OwenSchaub et al. 1995). An intriguing question remains as to whether induction of apoptosis by p53 requires: 1) the transcriptional activation of downstream genes, such as p21 WAF1, GADD45, cyclin G, Bax, and Fas; 2) direct interaction with already existing cellular proteins (Caelles et al. 1994; X.W. Wang et al. 1994; Thut et al. 1995; X.W. Wang et al. 1995b); or 3) both. Mounting evidence indicates that p53 is a potent inducer of apoptosis. Although these factors may modulate the sensitivity of cells to exogenous inducers of apoptosis, Bax or Fas do not induce apoptosis by themselves (Itoh et al. 1991; Oltvai et al. 1993), and no evidence has been published to date to indicate that $\mathrm{p} 21^{\mathrm{WAF} 1}, \mathrm{GADD} 45$, or cyclin $\mathrm{G}$ can induce apoptosis. In addition, previous studies have shown that inhibition of protein synthesis by cycloheximide can induce apoptosis in cultured cells in vitro (Bazar and Deeg 1992; Martin 1993; Raff et al. 1993) and rat pancreatic acinar cells in vivo (Harris et al. 1968), and more recent studies (Caelles et al. 1994; Haupt et al. 1995; Rowan et al. 1996) have suggested that p53-mediated apoptosis did not require the activation of downstream genes. These and other studies indicate that factors needed for apoptosis are constitutively present in cells.

We and others recently showed that p 53 selectively binds to (X.W. Wang et al. 1994; Xiao et al. 1994; X.W. Wang et al. 1995b) and inhibits the DNA helicase activities of the TFIIH-based transcription-repair complex by binding to its subunits XPB and XPD (X.W. Wang et al. 1995b|, which have dual roles in transcription and nucleotide excision repair (NER) (Feaver et al. 1993; Schaeffer et al. 1993; Cleaver 1994; Drapkin et al. 1994; Schaeffer et al. 1994). Binding is mediated through the CTD of p53 and the helicase motif III of XPB (X.W. Wang et al. 1995b). We propose that in response to DNA damage, p53 binding to TFIIH either modulates DNA-repair effi- ciency or triggers apoptosis. To investigate this hypothesis, we utilized microinjection and retroviral transfer of the p53 expression vector to initiate the apoptotic process in individual normal or mutant primary human fibroblasts. This enabled us to examine the functional interactions between p53 and TFIIH and to identify the TFIIH-associated factors XPB and XPD as components of the p53-dependent apoptotic pathway.

\section{Results}

Wild-type p53 induces apoptosis in primary human fibroblasts

Various oncogene products, including the adenovirus early region 1A $(E 1 A)$ gene, E2F-1 or c-myc, can increase the sensitivity of rodent fibroblasts to undergo apoptosis (Bissonnette et al. 1992; Evan et al. 1992; Debbas and White 1993; Lowe and Ruley 1993; Qin et al. 1994; Wu and Levine 1994). One cellular response that these oncogenes share with DNA damage induced by ultraviolet light or ionizing radiation, is the accumulation of the p53 protein (Kastan et al. 1992; Debbas and White 1993; Lowe and Ruley 1993; Lu and Lane 1993; Hermeking and Eick 1994; Wu and Levine 1994). We chose to use primary human fibroblasts because early passage cells from normal donors and donors with genetic diseases are available. Although these cells are less sensitive to inducers of apoptosis, such as ionizing irradiation, when compared to human lymphocytes, one can induce the apoptotic response by retroviral transfer or microinjection of p53 expression constructs (X.W. Wang et al. 1995a) (data not shown). We initially used a microinjection technique to deliver an expression vector encoding wild type p53 under the control of the cytomegalovirus (CMV) early promoter into the nuclei of the normal human primary fibroblasts (GM07532). Increased levels of wild type p53 were observed $24 \mathrm{hr}$ following injection, predominantly in the nucleus or in both the nucleus and

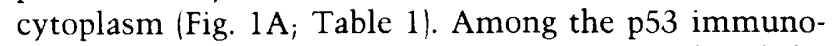
positive cells at $24 \mathrm{hr}$, an average of $26 \%$ displayed the typical characteristic features of apoptosis, including chromatin condensation, nuclear fragmentation, and apoptotic bodies (Fig. IB and data not shown). The timecourse study indicates that the percent of the p53-positive apoptotic cells remaining attached to the coverslip was increased up to $60 \%$ at $72 \mathrm{hr}$, whereas the total number of p53-positive cells was significantly decreased, indicating the progressive detachment of the apoptotic cells (data not shown). These results suggest that the majority of cells expressing p53 eventually die via apoptosis. As a control, microinjection of the $\beta$-galactosidase expression vector did not result in a significant elevation of apoptosis of primary normal human fibroblasts up to 72 hr (data not shown). Similar results were obtained when either fused normal fibroblasts (C5RO) from a different donor (Vermeulen et al. 1994a) or unfused primary human mammary epithelial cells were used (L. Elmore, X.-W. Wang, and C.C. Harris, unpubl.).

To determine whether induction of apoptosis was spe- 

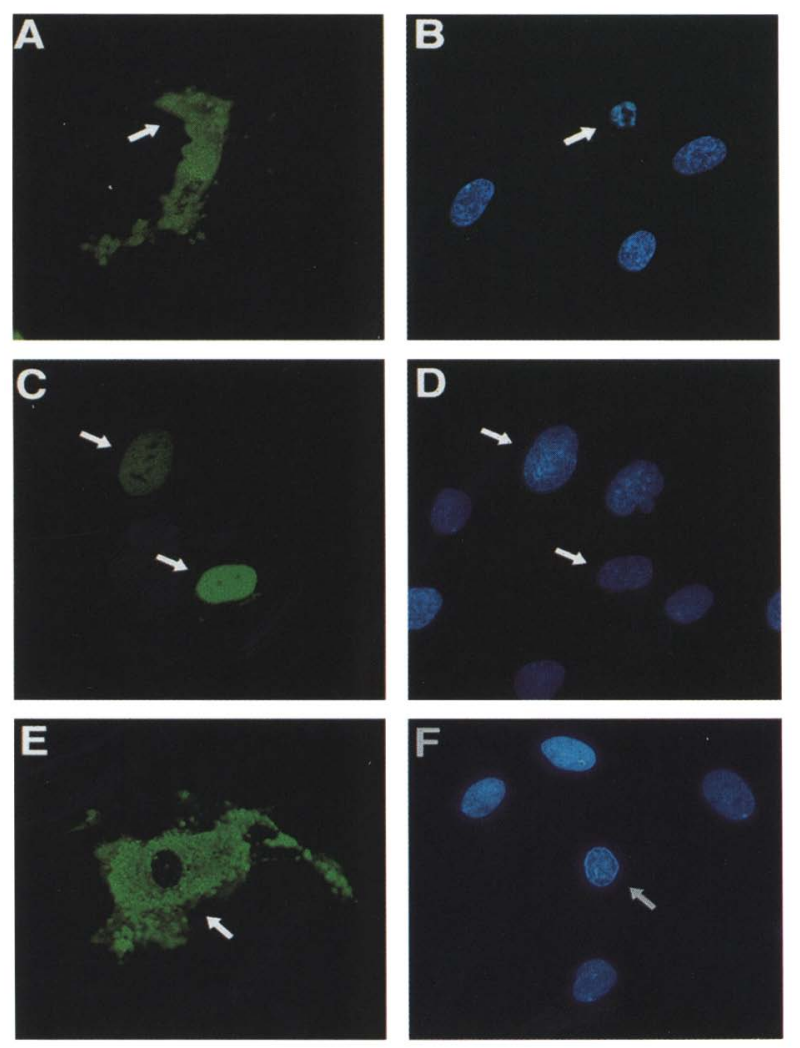

Figure 1. Induction of apoptosis by microiniection of wild-type and various mutant p53 expression vectors in normal primary human fibroblasts (GM07532). Cells were injected with the following p53 expression vectors: wild-type $(A, B) 143^{\text {ala }}(C, D)$, and $249^{\text {ser }}(E, F)$, and were incubated for $24 \mathrm{hr}$ prior to fixation. p53 protein was stained with CM-1 antibody $\{A, C, E)$. Nuclei were stained by DAPI $(B, D, F)$.

cifically attributable to an intrinsic activity of wild-type p53 and not the result of nonspecific protein overproduction, p53 mutants $143^{\text {ala }} 175^{\text {his }}, 248^{\text {trp }}$ or $249^{\text {ser }}$, in the same expression vector system, were microinjected. These p53 mutants lack the sequence-specific transcriptional trans-activation activity that is associated with growth suppression (Kern et al. 1992; Crook et al. 1994; Pietenpol et al. 1994). All mutants were expressed at similar or higher protein levels than wild-type p53 (Fig. $1 \mathrm{C}, \mathrm{E}$ and $\mathrm{X} . \mathrm{W}$. Wang. et al., unpubl.). The p53 mutants showed similar subcellular localization as wild type p53, except for the $249^{\text {ser }}$ mutant, that accumulated predominantly in the cytoplasm (Fig. 1C,E and X.W. Wang et al., unpubl.). All mutants lacked the ability to induce apoptosis (Table 1). These data are consistent with previous results (Yonish-Rouach et al. 1991; Clarke et al. 1993; Lowe et al. 1993b/and indicate that an intrinsic property of wild-type p53 expressed in normal fibroblasts is the induction of apoptosis and loss of this ability by the p 53 mutants tested.

Mutation of the wild-type $p 53$ gene can result in a loss of tumor suppressor activity and in some cases, gain of oncogenic properties (Kern et al. 1992; Dittmer et al. 1993). To test whether p53 mutants can have dominant- negative effects, expression vectors encoding both wildtype and mutant $p 53$ were coinjected into primary fibroblasts. The presence of the mutants $143^{\text {ala }}, 175^{\text {his }}, 248^{\text {trp }}$ or $249^{\text {ser }}$, completely abolished the induction of apoptosis by wild-type $p 53$ (Table 1). When most of the mutants were coexpressed with wild-type $p 53$, the subcellular localization patterns were largely unaltered (Wang et al., unpubl.|. Interestingly, we observed a fewer number of cells with only cytoplasmic staining when wild-type $p 53$ was coinjected with the $249^{\text {ser }}$ mutant $(20 \%$ vs. $77 \%)$. These data indicate that although all p53 mutants tested exhibit dominant-negative effects, they may differ in the mechanism of inactivation of wild-type p53 function.

\section{p53-mediated apoptosis is defective in fibroblasts from XP-B or XP-D patients}

We recently observed that both wild-type and mutant p53 $\left(135^{\text {tyr }}, 249^{\text {ser }}\right.$ or $\left.273^{\text {his }}\right)$ bind to TFIIH-associated factors, but only wild-type p53 inhibits the TFIIH-associated DNA helicase activity contributed by XPB and XPD (X.W. Wang et al. 1994; X.W. Wang et al. 1995b). If this interaction is an important step in the activation of $\mathrm{p} 53$ mediated apoptosis, defects in the $X P D$ and $X P B$ genes could result in cells resistant to p53-induced apoptosis. Therefore we tested whether wild-type p53, under conditions that induce apoptosis in normal primary fibroblasts, had any effect on primary fibroblasts from xeroderma pigmentosum (XP) donors with XP-B and XP-D germ-line mutation. The cells from patients XPCS2BA and XPCS1BA (sibling of XPCS2BA) contain a missense mutation at codon $99^{\text {phe } \rightarrow \text { ser }}$ in the $X P B$ gene, and cells from patient XP11BE have a frameshift mutation near the carboxyl terminus of the $X P B$ gene. These mutations result in a nearly complete inactivation of the NER function of this protein (Weeda et al. 1990; Vermeulen et al. 1994a). Tvhe cells from patient XP6BE contain a defective $X P D$ gene that also severely affects its NER activity (Flejter et al. 1992). Microinjection of the wild-type p53

Table 1. Induction of apoptosis by wild-type or mutant p53 in normal primary human fibroblasts

\begin{tabular}{|c|c|c|}
\hline Expression vectors & Percent apoptotic cells ${ }^{\mathrm{a}}\left\langle n^{\mathrm{b}}\right\rangle$ & $P$ value \\
\hline Wild-type p53 & $26(231)$ & \\
\hline $143^{\mathrm{ala}}$ & $0(18)$ & $<0.05$ \\
\hline $175^{\text {his }}$ & $0(38)$ & $<0.005$ \\
\hline $248^{\mathrm{trp}}$ & $0(36)$ & $<0.005$ \\
\hline $249^{\text {ser }}$ & $0(34)$ & $<0.005$ \\
\hline Wild type $+143^{\text {ala }}$ & $0(16)$ & $<0.05$ \\
\hline Wild type $+175^{\text {his }}$ & $0(17)$ & $<0.05$ \\
\hline Wild type $+248^{\operatorname{trp}}$ & $0(24)$ & $<0.01$ \\
\hline Wild type $+249^{\text {ser }}$ & $0(20)$ & $<0.05$ \\
\hline
\end{tabular}

${ }^{a}$ Cells with condensed and fragmented nuclei as well as the crater-like bodies characteristic of cells undergoing apoptosis at $24 \mathrm{hr}$ following microinjection of p53 expression vectors.

$b(n)$ Total number of p53 immunopositive cells following microinjection of p53 expression vectors. $\chi^{2}$ test was used for analyzing the statistical significance between wild-type p53 and mutant p53. 
expression vector into these cells resulted in elevated expression of nuclear p53 (Table 2; data not shown). The signal intensity of p53 in these cells was comparable to the levels in normal fibroblasts. Although $26 \%$ of the p53-positive normal cells underwent apoptosis, of the p53 immunopositive XP cells scored, only $5 \%$ of the XPCS1BA cells, $4 \%$ of the XPCS2BA cells, $7 \%$ of the XP11BE cells, and none of the XP6BE cells exhibited apoptosis at $24 \mathrm{hr}$ (Table 2). However, p53-mediated apoptosis was normal in primary fibroblasts from TTDlBR cells that have a mutation in a TFIIH-associated factor other than $X P B$ or $X P D$ gene (Table 2). Then we carried out a time-course study, in which cells were incubated for 6,24 , and $48 \mathrm{hr}$ following microinjection of the wildtype $p 53$ expression vector (Fig. 2). Although the enhanced signal intensity of $\mathrm{p} 53$ is similar in all cell types at $6 \mathrm{hr}$ following microinjection (data not shown), no apoptosis was observed at this time point. At $24 \mathrm{hr}, 20 \%$ of C5RO cells, but only $4 \%$ of XPCS2BA cells, had undergone apoptosis (Table 2, Fig. 2). Apoptosis was not observed in XP6BE cells. At $48 \mathrm{hr}$, however, $33 \%$ of both p53-positive C5RO and XPCS2BA cells and $9 \%$ of the p53-positive XP6BE cells had undergone apoptosis (Fig. 2). These data indicate that the p53-associated apoptosis is not completely abolished in these mutant cells, possibly attributable to either the remaining functional XP protein, that is, XPB or XPD, in the TFIIH complex or an alternative TFIIH-independent pathway.

To confirm the microinjection results and to determine whether wild-type p53-induced apoptosis occurs in fibroblasts from individuals with defects in DNA-repair genes other than $X P B$ and $X P D$, we infected primary fibroblasts from normal individuals and individuals with $\mathrm{XP}-\mathrm{A}$ and XP-C germ-line mutations with a retroviral wild-type $p 53$ expression vector under the control of the $\mathrm{CMV}$ promoter. Moderate levels of nuclear $\mathrm{p} 53$ protein expression were observed in the infected cell types tested when compared to microinjected cells (Fig. 3; data not shown). The p53 signal intensities are comparable

Table 2. Differential induction of apoptosis by microinjection of the wild-type p53 gene in primary human fibroblasts from individuals with various mutational defects in the nucleotide excision repair pathway

\begin{tabular}{lccc}
\hline $\begin{array}{l}\text { Cell } \\
\text { strains }^{\mathbf{a}}\end{array}$ & Phenotypes & $\begin{array}{l}\text { Percent apoptotic } \\
\text { cells }(n)^{\mathrm{b}}\end{array}$ & $P$ value \\
\hline GM07532 & normal & $26(231)$ & \\
TTD1BR & TTD-A & $17(52)$ & $>0.05$ \\
XPCS1BA & XP-B & $5(157)$ & $<0.001$ \\
XPCS2BA & XP-B & $4(113)$ & $<0.001$ \\
XP11BE & XP-B & $7(87)$ & $<0.001$ \\
XP6BE & XP-D & $0(95)$ & $<0.001$ \\
\hline
\end{tabular}

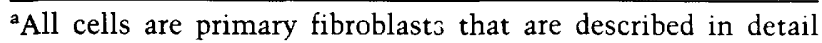
elsewhere (Kraemer et al. 1975; Vermeulen et al. 1991, 1994a; Weeda et al. 1990; Stefanini et al. 1993).

$\mathrm{b}(n)$ Total number of p53-immunopositive cells $24 \mathrm{hr}$ following microinjection of the wild-type p53 expression vector. $\chi^{2}$ was used for analyzing the statistical significance between normal cells and cells from XP donors.

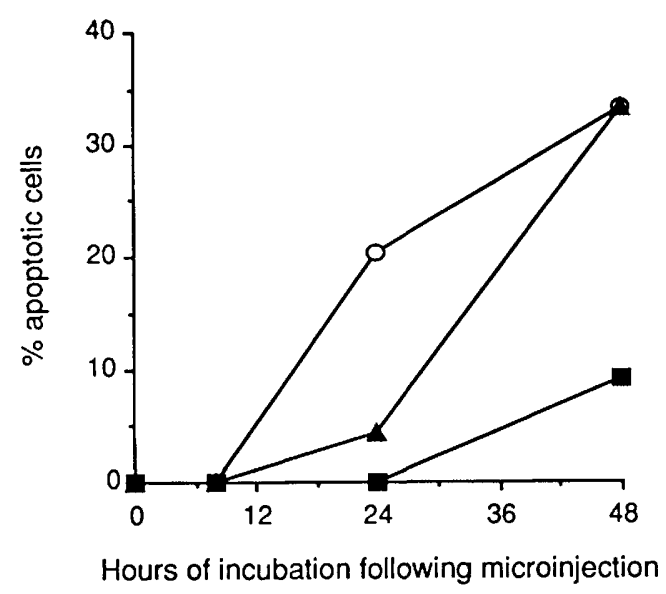

Figure 2. Differential induction of apoptosis between normal primary human fibroblasts $(O)$ and primary fibroblasts from xeroderma pigmentosum $[\mathrm{XP}-\mathrm{B}(\mathbf{A})$ and XP-D ( $\mathbf{\square})]$ donors following microinjection of the wild-type p53 expression vector.

among the infected cells, indicating no significant celltype differences in protein expression. Among the p53 immunopositive cells, $\sim 8 \%$ of normal cells (GM07532), $7 \%$ of the XP-C cells (XP1PW), and $6 \%$ of the XP-A cells (XP12BE) consistently exhibited apoptosis (Table 3). In contrast, only $1 \%$ of the p53-immunopositive XP-B cells (XPCS2BA) and none of the XP-D cells (XP6BE) exhibited the apoptotic phenotype (Table 3), which is consistent with the microinjection data. These results were confirmed in primary fibroblasts from an additional XP-B (XPCSIBA) donor and an XP-D (GM03248) donor (data not shown). Therefore, the decreased sensitivity to wildtype p53-induced apoptosis in XP-B and XP-D cells is not caused by either a general overall defect in the NER pathway or transcriptional defects associated with TFIIH /see Table 2 for the TTDIBR datal but is the result of a mutation in the $X P B$ or XPD gene.

\section{Wild-type $p 53$ retains its transcriptional trans-activator activity in XP-B and XP-D cells}

To demonstrate further that the microinjected wild-type p53 gene was efficiently expressed in XP-B and XP-D cells, and the p53 protein where transiently expressed, retains a wild-type specific function such as sequencespecific transcriptional trans-activator activity, we first tested the ability of the wild-type $p 53$ retroviral vector to induce $\mathrm{p} 21^{\mathrm{WAF} 1}$ expression in normal (GM07532), XP-D (XP6BE) and XP-B (XPCS2BA) cells (Fig. 3). Although p53 was undetectable in control vector or uninfected cells by immunocytochemistry, infection of the wild-type $p 53$ retroviral vector resulted in nuclear colocalization of an elevated $\mathrm{p} 53$ protein and $\mathrm{p} 21^{\mathrm{WAF} 1}$ protein in all three cell types (Fig. 3). About $5 \%$ of cells exhibited p2 $1^{\mathrm{WAF} 1}$ immunostaining in uninfected cells or in cells infected with the control vector, indicating p53-independent $\mathrm{p} 21^{\mathrm{WAF} 1}$ expression in a subset of the cells. Of the p53immunopositive cells, $98 \%$ of the normal cells, $99 \%$ of the XP-D, and $99 \%$ of the XP-B cells showed positive for 

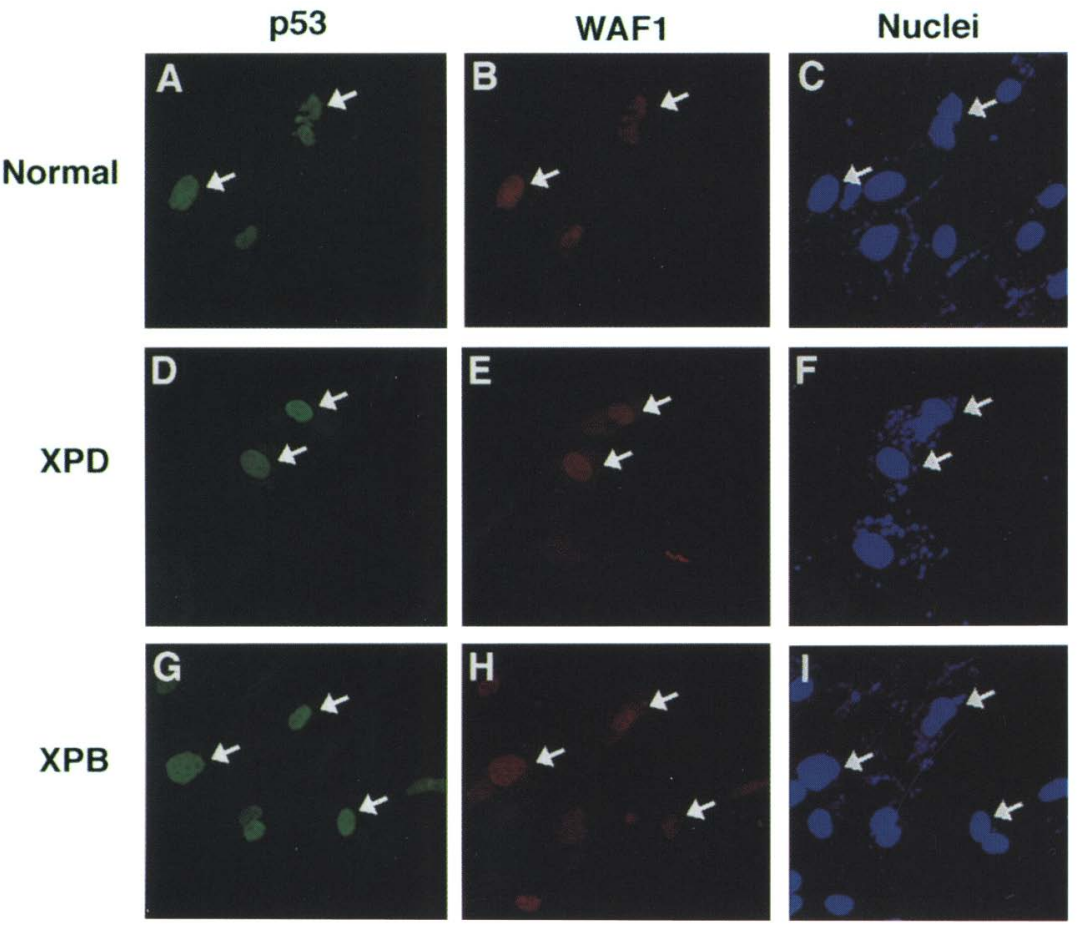

Figure 3. Induction of $\mathrm{p} 21^{\mathrm{WAF} 1}$ in normal primary human fibroblasts and in primary fibroblasts from xeroderma pigmentosum (XP-B and $\mathrm{XP}-\mathrm{D} /$ donors following infection by a retroviral vector encoding wild-type p53. Cells were infected with the wild-type p53 retroviral vector and incubated for $48 \mathrm{hr}$ prior to fixation. For simultaneous demonstration of p53 protein and p21 ${ }^{\text {WAF1 }}$ protein, GM07532 (normal) cells $(A-$ $C$, XP6BE (XP-D) cells $(D-F)$ and XPCS2BA (XP-B) cells $\{G-I \mid$ were double-labeled with anti-p53 rabbit polyclonal CM-1 antibodies $\{A, D, G\}$ and anti-p2 $21^{\mathrm{WAF} 1}$ monoclonal antibody (Oncogene Science) $(B, E, H)$, followed by the corresponding secondary antibodies conjugated to FITC for p53 and Texas Red for p21 WAF1, respectively. Nuclei were stained by DAPI $|C, F, I|$. the $\mathrm{p} 21^{\mathrm{WAF} 1}$ staining. The immunocytochemical intensity of $221^{\text {WAF1 }}$ is similar among these cells (Fig. 3), indicating a similar level of the wild-type p53 protein is achieved during infection.

Colocalization of the elevated $\mathrm{p} 53$ and $\mathrm{p} 21^{\mathrm{WAF} 1}$ proteins was also determined in these cells after microinjection of wild-type p53. At $6 \mathrm{hr}$ following microinjection of wild-type $p 53,25 \%$ of normal (GM07532) cells, $32 \%$ of XP-B (XPCS2BA) cells, and $34 \%$ of XP-D (XP6BE) cells showed positive for the p2 ${ }^{\mathrm{WAF} 1}$ staining. At $24 \mathrm{hr}$, overexpression of $\mathrm{p} 53$ resulted in an induction of nuclear $\mathrm{p} 21^{\mathrm{WAF} 1}$ in $50 \%$ of normal cells, $58 \%$ of XP-B cells and $54 \%$ of XP-D cells (Fig. 4B). No correlation between cells undergoing p53-mediated apoptosis and cells expressing $\mathrm{p} 21^{\mathrm{WAF} 1}$ was observed (data not shown). Although, overall, there were less $\mathrm{p} 21^{\text {WAF } 1}$-positive cells observed by microinjection as compared to cells with retroviral infection, there was no significant difference among the various cell types beginning as early as at $6 \mathrm{hr}$ incubation. Therefore, we concluded that wild-type p53 was efficiently expressed and retains its ability to trans-activate the p21 WAF1 gene (El-Deiry et al. 1993) in XP cells.

\section{Deficiency in p53-mediated apoptosis in XP-B and XP-D cells can be rescued by transferring a wild-type $\mathrm{XPB}$ or XPD gene}

To test genetically whether the deficiency in p53-medi- ated apoptosis in XP-B and XP-D cells is a result of a mutation in the $X P B$ or $X P D$ gene, we coinjected expression vectors for $p 53$ and wild-type $X P B$ or $p 53$ and $X P D$ gene into XP-B (XPCS2BA) or XP-D (XP6BE) cells, respectively. Although coinjection of the $X P B$ gene did not alter p53-mediated p $21^{\mathrm{WAF} 1}$ expression (Fig. 4B), it completely restored p53-mediated apoptosis in XP-B cells (Fig. 4B). Similarly, the XPD gene rescued p53-mediated apoptosis in XP-D cells, although the efficiency was lower than in the case of XP-B cells (Fig. 4B). Again, no alteration of $\mathrm{p} 53$-mediated $\mathrm{p} 21^{\mathrm{WAF} 1}$ expression was observed in these cells (Fig. 4B). As a control, the $X P B$ or $X P D$ gene alone was injected into XP-B or XP-D cells, respectively. No morphological changes were observed (data not shown). These data strongly indicate that the $X P B$ and/or $X P D$ gene products are components in the p53-dependent apoptosis pathway.

\section{Carboxyl terminus of p53 contributes to its apoptotic activity}

We have shown previously that the CTD of p53 /residues 367-393) is responsible for interaction with XPB and XPD (X.W. Wang et al. 1995b). The Pab421 monoclonal antibody recognizes an epitope in the CTD of p53 within this binding region (Banks et al. 1986) and can disrupt interaction between $\mathrm{p} 53$ and XPB in vitro (X.W. Wang et al. 1995b) (data not shown). We hypothesized that if $\mathrm{p} 53$ 
Table 3. Differential induction of apoptosis by infection of a retroviral vector encoding wild-type p53 in fibroblasts from individuals with various defects in nucleotide excision repair

\begin{tabular}{|c|c|c|c|}
\hline Cell name ${ }^{a}$ & Phenotypes & $\begin{array}{l}\text { Percent } \\
\text { apoptosis } \\
\text { (mean } \pm \text { S.D.) }\end{array}$ & $n^{\mathrm{b}}$ \\
\hline 1057 (GM07532) & normal & $8.3 \pm 2.4$ & 402 \\
\hline XP1PW (GM00510) & $\mathrm{XP}-\mathrm{C}$ & $7.0 \pm 0.5$ & 497 \\
\hline XP12BE (GM05509B) & $\mathrm{XP}-\mathrm{A}$ & $5.7 \pm 1.5$ & 344 \\
\hline XPCS2BA (GM13026) & XP-B & $1.0 \pm 0.3$ & 533 \\
\hline XP6BE (GM10430) & XP-D & 0 & 448 \\
\hline
\end{tabular}

${ }^{a}$ All cells are primary fibroblasts between passage 10 and 15 obtained from Coriell Institute for Medical Research. The cell names correspond to their local user numbers from initial publications or their catalog numbers. XP-A, XP-B, XP-D, and XP-C designate xeroderma pigmentosum complementation group $\mathrm{A}$, $B, D$, and $C$, respectively. Induction of apoptosis was achieved by infection of these cells with a retroviral vector encoding wild-type p53 under the control of the CMV promoter in the presence of Polybrene, followed by an additional $48 \mathrm{hr}$ incubation. The titer of viral stocks used is $1 \times 10^{5} \mathrm{CFU} / \mathrm{ml}$, and only one viral stock was used for all experiments to avoid variation. Cells were fixed, stained for p53, and analyzed for apoptosis as described (Vermeulen et al. 1994a). The p53 signal intensities are comparable among the cells tested, indicating no significant difference in protein expression (not shown). Percent apoptosis is calculated by scoring only the p53-immunopositive cells. Data are an average of three independent experiments. Student's $t$-test was used for analyzing the statistical significance between normal cells and cells from XP donors. XP-C and XP-A cells have a $P$ value $>0.05$, and XP-B and XP-D cells have a $P$ value $<0.001$ when compared to GM07532 cells.

$\mathrm{b}(n)$ Total number of p53-immunopositive cells scored.

induces apoptosis by direct interaction with XPB and/or $\mathrm{XPD}$, coinjection of $\mathrm{p} 53$ with Pab421 would block this effect. As shown in Figure $4 \mathrm{~A}$, whereas $26 \%$ of the $p 53$ injected normal cells (GM07532) underwent apoptosis, only $6 \%$ of the p53 plus Pab421-injected normal cells exhibited apoptosis $\{P<0.05$, as compared to wild-type alone or wild-type plus mIgG). In contrast, the Pab421 antibody enhanced $\mathrm{p} 53$-mediated $\mathrm{p} 21^{\mathrm{WAF} 1}$ expression in these cells from $45 \%$ to $90 \%$ (Fig. $4 \mathrm{~A}$ ), which is consistent with our findings that a majority of the p53 expressed in microinjected cells exhibited a transcriptional trans-activation-incompetent form, as well as the previously published data that Pab421 can enhance the p53 sequence-specific DNA-binding activity in vitro that is required for its transcriptional trans-activation activity in vivo (Hupp et al. 1992). Coinjection of wild-type p53 and normal mouse IgG (Fig. 4A) or injection of Pab421 alone (data not shown) into GM07532 cells did not result in any significant alteration in the p53-mediated apoptosis and $\mathrm{p} 21^{\mathrm{WAF} 1}$ induction. The fact that the Pab421 antibody competes for p53 binding to XPB in vitro and inhibits p53-mediated apoptosis in vivo, argues further that p53-mediated apoptosis in normal primary fibroblasts involves direct interaction of $\mathrm{p} 53$ with the XPB or $\mathrm{XPD}$ protein.
To demonstrate further whether the p53 carboxy-terminal peptide exhibits apoptotic activity, we microinjected peptides into normal primary human fibroblasts. Whereas a control peptide derived from hepatitis B virus $X$ protein had no effect on cell growth, the p53 carboxyterminal peptide (amino acid residues 319-393) at equal molar efficiently induced apoptosis of primary normal human fibroblasts (Table 4). Additional studies are required to determine the specific regions, for example, tetramerization or epitope of Pab421, in the p53 CTD that mediate the apoptotic response.

\section{Transcriptional trans-activator activity of p53} is dispensable for p53-mediated apoptosis

The ability of wild-type p53 to induce the p $21^{\mathrm{WAF} 1}$ expression in the XP-B or XP-D cells raises an intriguing question as to whether transcriptional activation of downstream genes is required for induction of apoptosis

\section{A Normal Cells (GM07532)}



B XP Cells

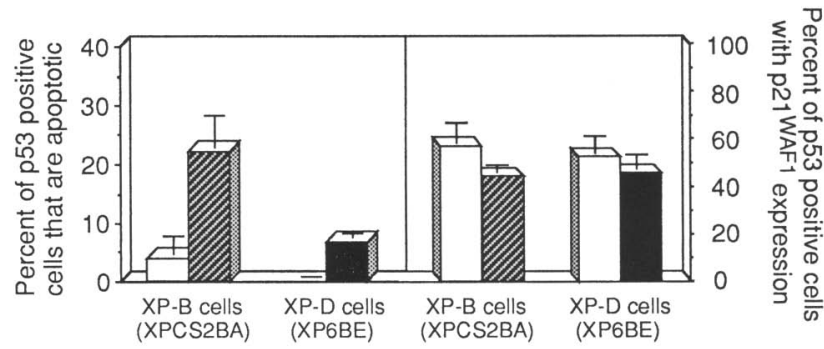

Figure 4. Effects of Pab421 monoclonal antibody and $X P B$ or $X P D$ genes on $\mathrm{p} 53$-mediated apoptosis. Coinjection of $\mathrm{p} 53$ with Pab421 antibody $(A)$ or a combination of p53 with the $X P B$ or $X P D$ gene $(B)$ was performed to compare the effect of these genes on p53-mediated apoptosis or trans-activation activity following a 24-hr incubation. This included microinjection of $\mathrm{p} 53$ alone into normal (GM07532), XP-B (XPCS2BA), or XP-D (XP6BE) cells (open bars), coinjection of p53 + Pab421 antibody into normal cells (shaded bars), coinjection of p53+normal mouse IgG (mIgG) into normal cells (right-hatched bars), coinjection of p53 + XPB into XP-B cells (left-hatched bars), or coinjection of p53 + XPD into XP-D cells (solid bars). Data represent an average of at least three independent experiments that were performed on separate days. Note the difference in scale between the left and right panels. 
by p53. To test this hypothesis directly, we microinjected various $p 53$ mutant expression vectors into normal fibroblasts (GM07532) and compared their transcriptional trans-activator and apoptotic activities. Trans-activation activity of p53 is not correlated for its apoptotic activity (Fig. 5). For example, a multiple missense mutation at the CTD including codons His $364 \mathrm{Ala}$, Lys 372 Leu, Arg 379 Ala, and Lys 386 Leu (p53-517), a CTD deletion of the last 50 residues (p53 5353 ), or a germ-line mutation found in several types of cancers (p53 181 H) gave rise to $\mathrm{p} 53$ proteins that retained similar or greater levels of transcriptional trans-activation of either the endogenous $\mathrm{p} 21^{\mathrm{WAF} 1}$ gene (Fig. $5 \mathrm{~B}$ ) or a heterologous reporter containing multiple p53-binding sites $\left(\mathrm{PG}_{13} \mathrm{CAT}\right)$ (data not shown), as compared to wild-type p53. In contrast, these mutants had either reduced (p53-517) or abolished (p53 5353 and p53 $181 \mathrm{H}$ ) apoptotic activity (Fig. 5A). p53 mutant 273H had no detectable trans-activation activity; however, it retained a low degree of apoptotic activity (Fig. 5). In addition, microinjection of the $p 21^{W A F 1}$ cDNA under the control of CMV promoter gave rise to a high level of $\mathrm{p} 21^{\mathrm{WAF} 1}$ protein in GM07532 cells that accumulated predominantly in the nucleus but did not lead to apoptosis (data not shown). These data are
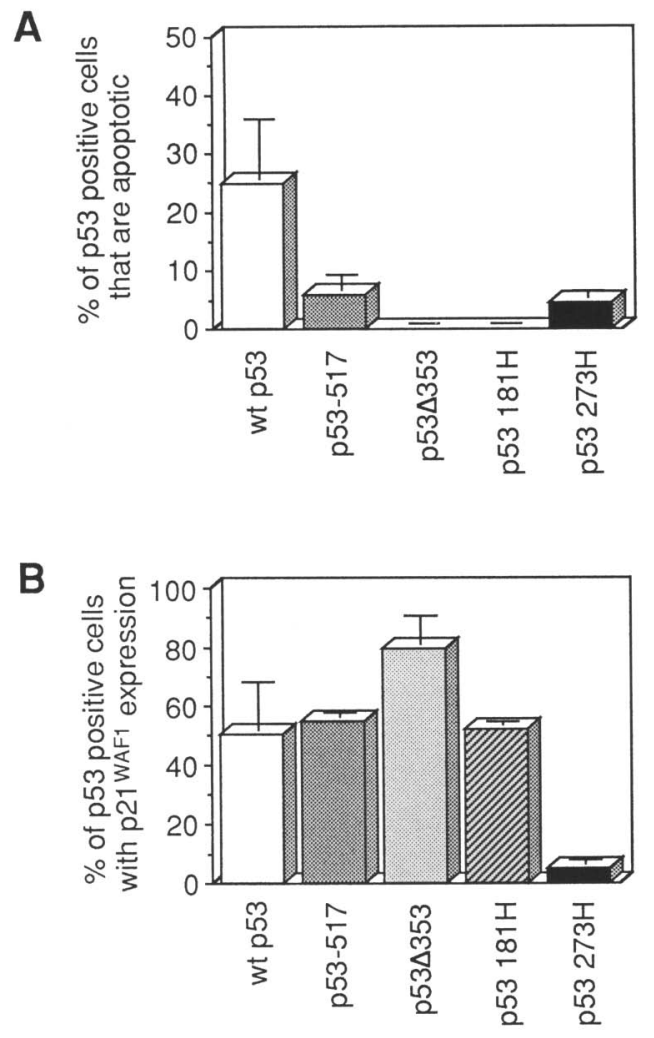

Figure 5. Transcriptional trans-activation activity of p53 is not correlated with p53-mediated apoptosis. Various p53 mutants were tested for their ability to induce apoptosis $(A)$ and activate the $\mathrm{p} 21^{\mathrm{WAF}}$ gene expression $(B)$ in normal primary human fibroblasts (GM07532) following $24 \mathrm{hr}$ incubation after microinjection. All data are an average of at least three independent experiments.
Table 4. Induction of apoptosis by microinjection of carboxy-terminal peptide of p53 in normal primary human fibroblasts

\begin{tabular}{lccc}
\hline & \multicolumn{3}{c}{ Percent apoptotic cells } \\
\cline { 2 - 4 } Peptides $^{\text {a }}$ & experiment 1 & experiment 2 & experiment 3 \\
\hline p53 & 42 & 43 & 21 \\
HBx & 3 & N.D. & 0 \\
\hline
\end{tabular}

a Peptide p53 corresponding to the amino acid residues 319-393 of the human wild-type p53 protein was provided by Kazuyasu Sakaguchi and Ettore Appella (National Cancer Institute, Bethesda, MD|. Peptide $\mathrm{HBx}$ corresponding to the amino acid residues $115-131$ of the hepatitis $B$ virus $X$ protein was provided by Mark Feitelson (Jefferson Medical College, Philadelphia, PA). Peptides at the concentration of $583 \mu \mathrm{M}$ were coinjected with the $\beta$-galactosidase expression vector $(100 \mu \mathrm{g} / \mathrm{ml})$ into primary human fibroblasts (GM07532). Following $24 \mathrm{hr}$ incubation, cells were fixed, double-stained for p53 and $\beta$-galactosidase, and analyzed for apoptosis as described earlier.

consistent with the Pab421 antibody and carboxy-terminal peptide microinjection results (Fig. 4; Table 4) and indicate that the CTD of $\mathrm{p} 53$ is required for induction of apoptosis.

Normal induction of apoptosis in normal, XP-B, and XP-D fibroblasts by the Ich-1 $\mathrm{L}_{\mathrm{L}}$ and ICE genes

To demonstrate further that the XP-B and XP-D cells were efficiently expressing the genes introduced, we microinjected the expression vectors containing the human apoptosis-inducing gene $\left(I \mathrm{ch}-1_{L}\right)$ or a mammalian Ced-3 homolog (ICE gene) into normal (GM07532), XP-B (GM13026), and XP-D (XP6BE) fibroblasts. These genes were fused to the $\beta$-galactosidase gene for detection of their protein expression (L. Wang et al. 1994). Microinjection of the Ich-1 $1_{L}$ gene resulted in elevated levels of Ich- $1_{\mathrm{L}}$ protein ( $\beta$-galactosidase activity). Among Ich- $1_{\mathrm{L}}$ positive cells scored, $49 \%$ of normal cells, $48 \%$ of XP-B cells, and $57 \%$ of XP-D cells underwent apoptosis (Fig. 6) with a typical apoptotic morphology essentially identical to that described previously (L. Wang et al. 1994), and to that induced by p53 (data not shown). It appears then that both XP-B and XP-D cells are normal in Ich- $1_{\mathrm{L}}$-mediated apoptosis. Similarly, the ICE gene also showed a comparable apoptotic activity among these cell types (Fig. 6). This suggests further that the defect in p53-mediated apoptosis in XP-B and XP-D cells is not attributable to subtle changes in transcriptional efficiency, as XP-B and XPD are also the subunits of the basal transcriptional factors that could lead to inefficient transcription of the injected gene in these cells but, rather, a result of a defect in the XPD gene in the p53-mediated apoptotic pathway.

\section{Lymphoblasts from XP-D patients have a deficiency in DNA damage-induced apoptosis}

To explore further whether XP-D cells are also defective in the DNA damage-induced and p53-dependent apop- 
Wang et al.

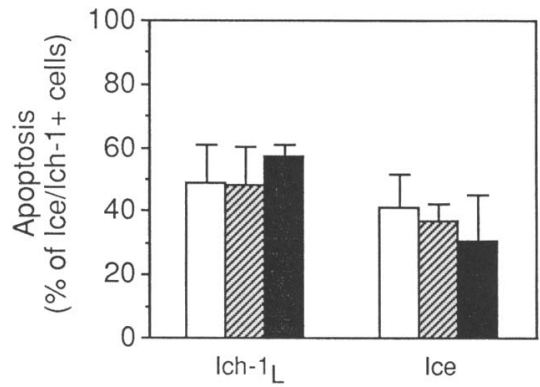

Figure 6. Induction of apoptosis in primary fibroblasts from normal (GM07532) (open bars), XP-B (XPCS2BA) (hatched bars), and XP-D (XP6BE) (solid bars) individuals by Ced-3/ICE-related genes. The appearance of apoptosis morphology following microinjection was monitored essentially as described (L. Wang et al. 1994). All data are an average of at least three independent experiments.

totic pathway, we compared the cell-killing effect of either the DNA-damaging agent adriamycin (p53-dependent) or okadaic acid (p53-independent) on lymphoblasts from a normal (GM02184C) and an XP-D donor (GM03249, whose fibroblasts, GM03248, were also deficient in p53-mediated apoptosis) (Fig. 7). Adriamycin or okadaic acid efficiently killed normal lymphoblasts in a time-dependent fashion (Fig. 7) via apoptosis as charac- terized by nuclear fragmentation. In XP-D lymphoblasts, however, adriamycin exhibited a consistent and statistically significant delay in the cell-killing effect (Fig. 7A). In contrast, both cell types appeared to have a normal response in the DNA damage-induced p53 accumulation (Fig. 7D). These results support the previous findings that adriamycin induced apoptosis through a p53-dependent pathway (Lowe et al. 1993a) and further implicate XP-D as being a component in DNA damage and the p53-dependent apoptosis pathway. Interestingly, okadaic acid appears to have an equally cytotoxic effect in both cells (Fig. 7B). Moreover, XP-D lymphoblasts appeared to have a normal response to Fas-mediated apoptosis induced by a cell-killing anti-Fas antibody (clone $\mathrm{CH}-11$ ) (data not shown). These data indicate that although XP-D cells are capable of undergoing apoptosis induced by 553 -independent pathways, these cells have a deficiency in DNA damage-induced apoptosis under conditions of physiological-relevant levels of p53.

\section{Discussion}

We have demonstrated that wild-type p53 can induce apoptosis in normal primary human fibroblasts. Many of the naturally occurring p53 mutants have lost their ability to induce apoptosis and exhibit a dominant-negative function to block wild-type p53-mediated apoptosis, a
A adriamycin



B okadaic acid

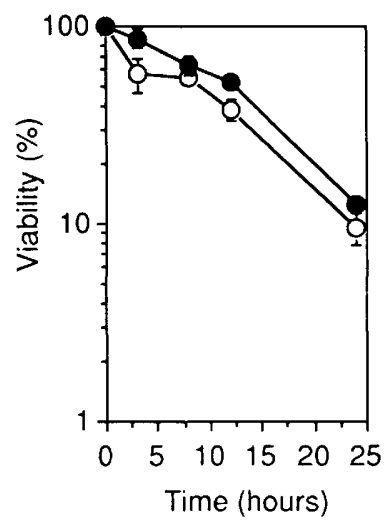

C

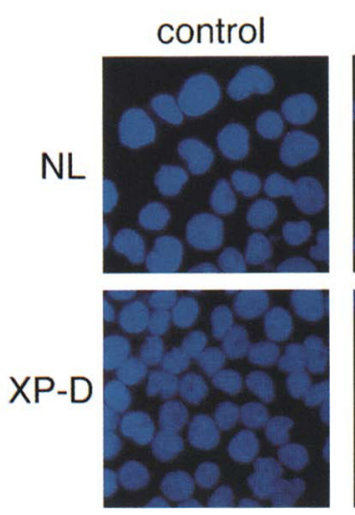

Figure 7. Induction of apoptosis in lymphoblasts from normal and XP-D patients by the other apoptosis inducers. Lymphoblasts from a normal individual (GM02184C; O) and an XP-D patient (GM03249; O) were incubated with media containing $17.2 \mu \mathrm{M}$ adriamycin $(A)$ or $0.5 \mu \mathrm{M}$ okadaic acid $(B)$. At various times following incubation, cell viability was measured by the method of trypan blue exclusion. Nuclear morphology $(C)$ of normal lymphoblasts (NL, GM02184C) and XP-D lymphoblasts (XP-D, GM03249) treated without (control) or with $17.2 \mu \mathrm{M}$ adriamycin or 0.5 $\mu \mathrm{M}$ okadaic acid for $24 \mathrm{hr}$. (D) Levels of p53 in lymphoblasts from normal (GM02184C) (lanes 1,2) and XP-D (GM03249) (lanes 3,4) individuals were monitored by Western blot analysis following treatment with (lanes 2,4) or without (lanes 1,3) $17.2 \mu \mathrm{M}$ adriamycin for $24 \mathrm{hr}$. Following adriamycin treatment, the p53 level was increased in both cell types 14.9-fold in normal cells and 6.4-fold in XP-D cells, as determined by densitometer analysis|.
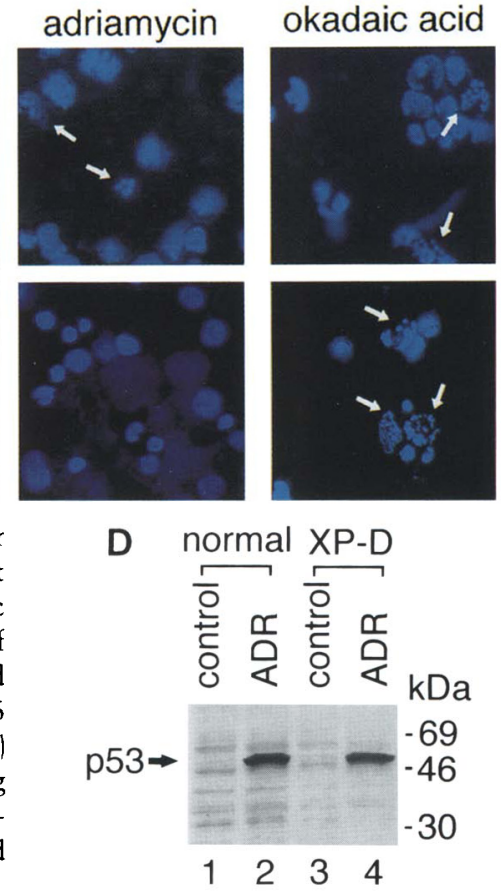
process closely associated with its tumor suppressor function (Yonish-Rouach et al. 1991; Clarke et al. 1993; Lowe et al. 1993b; Symonds et al. 1994). Induction of apoptosis by wild-type p53 in fibroblasts is not attributable to nonspecific protein overproduction but is a result of an intrinsic activity of wild-type p53, as many p53 mutants were expressed at much higher levels than wildtype p53, yet, no apoptosis was observed. The fact that these naturally occurring p53 mutants exhibit dominant-negative effects indicates that inactivation of wildtype p53 function is an important step in neoplastic transformation and further emphasizes that regulation of apoptosis by wild-type p53 is an integral part of the organism's defense mechanism against the outgrowth of cells with DNA damage that could lead to mutations in cancer-related genes (Symonds et al. 1994).

It has been a general notion that p53 induces apoptosis primarily in certain types of cells, such as those from the lymphoid system (Yonish-Rouach et al. 1991; Lowe et al. 1993b). In contrast, p53 induces growth arrest in fibroblasts (Kastan et al. 1992). Various oncogene products such as E1A, E2F-1, or c-Myc, however, have been shown to sensitize rodent fibroblasts to undergo p53-dependent apoptosis (Bissonnette et al. 1992; Evan et al. 1992; Debbas and White 1993; Lowe and Ruley 1993; Qin et al. 1994; Wu and Levine 1994). We found a relatively higher level of p53 expression and induction of apoptosis by microinjection than by retroviral infection, suggesting that a main determinant for a cell undergoing apoptosis or growth arrest may be the level of wild-type p53. Primary human fibroblasts may require higher levels of p53 than lymphocytes because of differences in the threshold required to trigger apoptosis. Because p53 also induces apoptosis in fused primary human fibroblasts that have lost proliferative potential and are arrested primarily in $\mathrm{G}_{1}$ of the cell cycle (Vermeulen et al. 1994a) (X.W. Wang et al., unpubl.), p53-mediated apoptosis, at least in fibroblasts, is independent of cell-cycle progression. This result is also consistent with a recent finding that Mycmediated apoptosis requires wild-type p53 in a manner independent of cell cycle-arrest (Wagner et al. 1994).

We have shown previously that $\mathrm{p} 53$ binds specifically to TFIIH-associated XPB and XPD and inhibits their helicase functions (X.W. Wang et al. 1994; 1995b). In this study we demonstrate that p53-induced apoptosis in primary human fibroblasts is directly associated with the function of the XPB and XPD proteins. The results are consistent with our previous hypothesis that the association of p53 with the TFIIH complex has a functional consequence in vivo and provide a basis for defining targets of p53-dependent apoptosis. The following observations are consistent with the hypothesis that p53-induced apoptosis can be mediated by the XPB and XPD DNA helicases. First, p53-mediated apoptosis is defective in fibroblasts from XP-B or XP-D patients that carry a germ-line mutation in the $X P B$ or $X P D$ gene, respectively. Second, expression of either wild-type $X P B$ or $X P D$ gene can rescue $\mathrm{p} 53$-mediated apoptosis in XP-B or $\mathrm{XP}-\mathrm{D}$ cells, respectively, which is further genetic evidence indicating that XPB and XPD are members of the p53-dependent apoptotic pathway. Third, this defect is not caused by an overall abolishment of NER activity because mutations involved in the NER genes other than $X P B$ or $X P D$ did not affect this pathway. Fourth, although mutations in the $X P B$ or $X P D$ gene did not completely abolish p53-mediated apoptosis, this partial defect does not appear to be the result of the XP cells being defective in transcription because the signal intensities of $\mathrm{p} 53$ and $\mathrm{p} 53$-induced $\mathrm{p} 21^{\text {WAF } 1}$ were comparable among normal, XP-B, or XP-D cells following introduction of $\mathrm{p} 53$. These cells also are normal in responding to Ich $-1_{L^{-}}$and ICE-induced apoptosis. In addition, primary fibroblasts from patient TTDIBR with the trichothiodystrophy syndrome (TTD) responded normally to p53mediated apoptosis, even though this patient carries a germ-line mutation in a TFIIH-associated factor other than the $X P B$ or $X P D$, which results in a severe defect in NER (Stefanini et al. 1993) and functional and anatomical defects related to a postulated transcription syndrome (Bootsma and Hoeijmakers 1993; Vermeulen et al. 1994b). Moreover, defects in p53-mediated apoptosis were also observed in XP-B- or XP-D-derived cells carrying mutations at different sites in these NER genes. The partial defect in apoptosis could reflect other signaling pathways (p53-dependent but TFIIH independent) that follow a different time course to trigger apoptosis. Alternatively, it can be explained by a partial deficiency in either the XPB- or XPD-dependent apoptotic pathway in these cells becuase there is always one functional XP protein, that is, XPB or XPD, remaining in the TFIIH complex. We interpret the second possibility as a more likely explanation. Fifth, the Pab421 antibody specifically recognizes the CTD of p53 (amino acid residues 373-381) involved in binding to XPB and XPD. This antibody can compete binding of $\mathrm{p} 53$ to $\mathrm{XPB}$ in vitro /data not shown). Consistent with this observation is the finding that the microinjected Pab421 also blocked p53-mediated apoptosis in vivo (Fig. 4). In contrast, p53-mediated trans-activation activity was either enhanced or unaltered (Fig. 4 and 5). Finally, XP-D lymphoblasts, which are defective in $\mathrm{p} 53$-mediated apoptosis, as demonstrated by treatment with a DNA-damaging agent, are still capable of undergoing apoptosis by other cell death inducers including okadaic acid (Fig. 7B) and anti-Fas antibody (data not shown). Taken together, these data are consistent with the model that p53-mediated apoptosis is a result of a direct interaction between p53 and the XPB and XPD proteins in the TFIIH complex.

The Ich-1 $1_{L}$ and ICE gene-induced apoptosis in normal as well as XP-B and XP-D cells, indicate that these Ced-3 mammalian homologs could use either a separate or a TFIIH downstream pathway to trigger cell death and that XP-B and XP-D cells retain all functional factors needed for the p53-independent or TFIIH downstream apoptotic pathway. Interestingly, the Ced-3/ICE-related gene products were shown to be relatively downstream of various apoptotic pathways including Fas-mediated apoptosis (Enari et al. 1995; Los et al. 1995). It will be interesting to identify the functional relationship between TFIIH and Ced-3/ICE gene products in the general apoptotic pathway. 
p53 is frequently mutated in many types of human cancer (for review, see Hollstein et al. 1991; Levine et al. 1991; Greenblatt et al. 1994). Loss of the wild-type p53 function by mutations appears to be an important step in carcinogenesis. p53 is clearly demonstrated to be involved in transcriptional trans-activation, leading to activation of downstream genes, for example, p21 $1^{\text {WAF }}$ (ElDeiry et al. 1993), or GADD45 (Kastan et al. 1992; Zhan et al. 1994|, contributing to the $\mathrm{G}_{1}$ cell-cycle checkpoint. Although most of the p53 mutants derived from human cancers appear to be defective in both transcriptional trans-activation and tumor suppression (Kern et al. 1991, 1992; El-Deiry et al. 1992; Pietenpol et al. 1994), an intriguing question concerning whether the transcriptional trans-activator property of $\mathrm{p} 53$ is always required for its tumor suppression function is still under debate (Crook et al. 1994; Rowan et al. 1996). We analyzed a group of p53 mutants and showed a clear correlation between mutants that were still able to trans-activate but had diminished apoptotic activity (Fig. 5), which is a function positively correlated with tumor suppressor activity (Lowe et al. 1994; Symonds et al. 1994). In contrast, one p53 mutant, $273^{\text {his }}$ that was shown to retain partial tumor suppressor function (Chen et al. 1991; Slingerland et al. 1993) and some apoptotic activity (Fig. 5 ), had no detectable trans-activation activity in human fibroblasts. Strasser and colleagues (1994) suggest that cell-cycle arrest (possibly by p53-mediated trans-activation of the $p 21^{W A F 1}$ and/or GADD45 genes) and apoptosis may be independent outcomes following treatment with cytotoxic agents. Whereas p53-induced apoptosis has an important mechanistic role in p53-mediated tumor suppression (Lowe et al. 1994; Symonds et al. 1994), transcriptional trans-activation and trans-repression by p53 may not be necessary for its tumor suppressor activity (Crook et al. 1994). Moreover, a recent study (Caelles et al. 1994) indicates that protein synthesis is not required for the p53-induced apoptosis. Mice lacking p21 ${ }^{\text {WAF1 }}$ undergo normal development and normal apoptotic response but are defective in $G_{1}$ checkpoint control, and these mice (unlike p53-/ -) do not have an increased frequency of spontaneous malignancies (Agarwal et al. 1995). Therefore, transcriptional trans-activator property of $\mathrm{p} 53$ may be dispensable for its tumor suppressor activity, and the data presented here further emphasize the possible importance of protein-protein interactions between p53 and other cellular factors in its apoptotic or tumor suppression pathway. Interestingly, Haupt et al. (1995) recently presented evidence indicating that p53-induced apoptosis is independent of sequence-specific trans-activation, Wagner et al. (1994) showed that Myc-mediated apoptosis requires p53 in a manner independent of the ability of p53 to induce p2 $1^{\text {WAF1 }}$, and Sabbatini et al. (1995) suggested a requirement of p53-mediated transcription in E1A-induced apoptosis. It is likely that both p53-mediated transcriptional trans-activator-dependent and -independent apoptotic pathways exist and are interactive, and this interaction may vary among cell types.

Our studies indicate that the microinjected p53 car- boxy-terminal peptide (amino acid residues 319-393) can directly induce apoptosis of primary human fibroblasts, suggesting that this region contains a death domain that is required for binding to XPB and XPD proteins and for induction of apoptosis. Interestingly, a recent report indicates that the amino-terminal half of p53 (amino acid residues $1-214$ ) is sufficient for induction of apoptosis in HeLa cells (Haupt et al. 1995). It is unclear how this amino-terminal half of p53 triggers apoptosis in HeLa cells. However, the p53-mediated transcription activator activity is not required in this system because this mutant is defective in trans-activation (Haupt et al. 1995). Nevertherless, although XPB and XPD are important for the CTD of p53-induced apoptosis in our system, alternative pathways may exist that use different targets. The fact that the XP-D or XP-B fibroblasts were not completely defective in p53-mediated apoptosis is consistent with this hypothesis. It will be interesting to test whether the amino-terminal half of p53 can induce apoptosis in normal human cells.

XPB and XPD are part of the TFIIH complex that is involved in basal transcription, NER, and possibly the control of cell cycle via its interaction with a cyclindependent kinase (CDK), CDK-activating kinase (CAK) (Schaeffer et al. 1993; Sung et al. 1993; Drapkin et al. 1994; Feaver et al. 1994; Roy et al. 1994a,b; Schaeffer et al. 1994). Our results indicate that TFIIH also plays a role in a p53-dependent apoptotic pathway. It is possible that these four essential cellular processes utilize the same core TFIIH protein complex and have a number of steps in common. A dynamic interaction among these factors may be required in various circumstances to modulate different cellular functions. For example, CAK is not associated with core-TFIIH when the complex is needed for NER (Z. Wang 1994; Svejstrup et al. 1995) but is tightly bound to core-TFIIH when the complex is competent for basal transcription (Feaver et al. 1994; Roy et al. 1994a; Svejstrup et al. 1995). In contrast, core-TFIIH is associated with other repair factors when it is required for NER (Svejstrup et al. 1995). It is plausible that the core-TFIIH complex may also bind to factors involved in the apoptotic pathway, one of the candidates being the p53 tumor suppressor protein. It will be interesting to identify additional factors downstream of the p53-TFIIH complex that are important in this apoptotic pathway.

Cancer therapy may inhibit tumor growth by triggering p53-dependent apoptosis through DNA damage. The results reported here provide a strategy to design new therapeutic agents that would bypass the requirement for $\mathrm{p} 53$ and directly target downstream members, that is, $\mathrm{XPB}$ and $\mathrm{XPD}$, in this apoptotic pathway.

\section{Materials and methods}

Plasmids

pC53SN encodes the human wild-type p53 cDNA. p53-143 ${ }^{\text {ala }}$, p53-175 his $, p 53-248^{\text {trp }}, p 53-249^{\text {ser }}$, and $p 53-273^{\text {his }}$ encode a single mutant p53, Vall-43-Ala, Arg-175-His, Arg-248-Trp, Arg249-Ser, or Arg-273-His, respectively. These constructs were kindly provided by B. Vogelstein and J. Pietenpol (Johns Hop- 
kins University). p53-181 ${ }^{\text {his }}$, a gift of S. Friend (Fred Hutchinson Cancer Center), encodes a mutant p53 Arg-181-His. p53-517, provided by H.-W. Sturzbacher (Sturzbecher et al. 1992), encodes p53 cDNA with four missense mutations, His-365-Ala, Lys-372-Leu, Arg-379-Ala, and Lys-386-Leu. p53 353 , encoding the first 353 amino acids of p53, was kindly provided by J. Pietenpol and B. Vogelstein. pCEPE 3 encodes a wild-type XPD cDNA inserted into the pCEP4 vector at the BamHI and HindIII sites (Invitrogen). pcDNA-XPD encodes a wild-type XPD cDNA inserted into the pCDNA3 vector at the EcoRI site (Invitrogen). All genes are under the control of the CMV promoter. $I C h-1_{L}$ and ICE genes have been described elsewhere (L. Wang et al. 1994).

Cell strains, culture condition, microinjection, and viral infection

Cell strains, culture conditions, cell hybridization, and microinjection were essentially as described (Vermeulen et al. 1994a). Primary human fibroblasts were grown in Ham's F10 medium supplemented with $10 \%$ FBS. Cells were seeded onto coverslips and incubated for an additional 2-3 days prior to microinjection. In some experiments, cells were fused by $\beta$-propiolactone-inactivated Sendai virus and the fused cells were used for microinjection. Plasmid cDNA, in a concentration of $100-200 \mu \mathrm{g} / \mathrm{ml}$ suspended in PBS, was injected into the nuclei of cells by use of a glass microcapillary. For each experiment, at least 50 cells were injected. Many of the microinjections were performed in part on the same slide when wild type was compared to various mutants or with the same needle when different types of cells were used to minimize variations caused by differences in immunostaining, processing of the slides, or vector copy numbers, and so forth. For viral infection, a single viral stock was used to infect cells in the presence of $8 \mu \mathrm{g} / \mathrm{ml}$ of polybrene.

\section{Immunocytochemistry analysis}

Following incubation, cells were fixed with $2 \%$ paraformaldehyde (in PBS) followed by methanol treatment. p53 was visualized by staining cells with the anti-p53 polyclonal CM-1 antibody (Signet Labs) followed by fluorescein-conjugated anti-rabbit IgG (Vector Labs, Burlingame, CA). Nuclei were stained with 4', 6-diamidino-2-phenylindole (DAPI). For simultaneous demonstration of $\mathrm{p} 53$ and $\mathrm{p} 21^{\mathrm{WAF} 1}$ proteins, cells were double-labeled with CM-1 antibodies $(1: 200)$ and anti-p2 $1^{\text {WAFI }}$ monoclonal antibody (Oncogene Science) (1:100), followed by the corresponding secondary antibodies conjugated to fluorescein isothiocyanate (FITC) and Texas Red, respectively.

\section{Cell viability assay and Western blot analysis.}

Lymphoblasts, obtained from Coriell Institute for Medical Research (Camden, NJ), were maintained in RPMI1640 medium containing $20 \%$ FBS. Exponentially growing cells were plated at a density of $6.25 \times 10^{5}$ cells per ml. Adriamycin and okadaic acid (Sigma) were used at concentrations of 17.2 and $0.5 \mu \mathrm{M}$, respectively. Cell viability was assessed by trypan blue exclusion. For Western blot analysis, lymphoblasts were treated with adriamycin as above for $24 \mathrm{hr}$. Cells were lysed in RIPA buffer $1150 \mathrm{~mm}$ $\mathrm{NaCl}, 1 \% \mathrm{NP} 40,0.5 \%$ DOC, $0.1 \%$ SDS, $50 \mathrm{~mm}$ Tris- $\mathrm{HCl}$, pH8.0). Total cellular proteins were subjected to immunoprecipitation with anti-p53 DO-1 antibody (Oncogene Science) essentially as described (X.W. Wang et al. 1995b). Immunoprecipitates were separated on $10 \%$ SDS-PAGE, transferred to a nitrocellulose membrane, and probed with polyclonal anti-p53 CM-1 antibody by the method of ECL (Amersham, Arlington Heights, IL).

\section{Acknowledgments}

We thank B. Vogelstein and J. Pietenpol for the plasmids of $\mathrm{pG}_{13} \mathrm{CAT}$, p21 WAF1, and various p53 mutants, H.-W. Sturzbacher for the $\mathrm{p} 53-517$ vector, $\mathrm{S}$. Friend for the $\mathrm{p} 53181 \mathrm{H}$ vector, and J.Y. Yuan for the ICh-1 and ICE cDNA clones. We are grateful to J.-M. Egly for advice, B. Gerwin for critical reading of the manuscript, P. Shields for statistical analyses, G. Best for photographic art work, and D. Dudek for editorial assistance. W.V. and J.H.J.H. gratefully acknowledge financial support from the Dutch Cancer Society (project EUR 94-763) and the section Medica Sciences of the Dutch Scientific Organization (project 501-93 and 151). M.G. and H.Y. were Howard Hughes Medical Institute-National Institutes of Health Research Scholars.

The publication costs of this article were defrayed in part by payment of page charges. This article must therefore be hereby marked "advertisement" in accordance with 18 USC section 1734 solely to indicate this fact.

\section{References}

Agarwal, M.L., A. Agarwal, W.R. Taylor, and G.R. Stark. 1995. p53 controls both the $G_{2} / M$ and the $G_{1}$ cell cycle checkpoints and mediates reversible growth arrest in human fibroblasts. Proc. Natl. Acad. Sci. 92: 8493-8497.

Bakalkin, G., T. Yakovleva, G. Selivanova, K.P. Magnusson, L. Szekely, E. Kiseleva, G. Klein, L. Terenius, and K.G. Wiman. 1994. p53 binds single-stranded DNA ends and catalyzes DNA renaturation and strand transfer. Proc. Natl. Acad. Sci. 91: 413-417.

Banks, L., G. Matlashewski, and L. Crawford. 1986. Isolation of human-p53-specific monoclonal antibodies and their use in the studies of human p53 expression. Eur. I. Biochem. 159: 529-534.

Bayle, J.H., B. Elenbaas, and A.J. Levine. 1995. The carboxyterminal domain of the p53 protein regulates sequence-specific DNA binding through its nonspecific nucleic acid-binding activity. Proc. Natl. Acad. Sci. 92: 5729-5733.

Bazar, L.S. and H.J. Deeg. 1992. Ultraviolet B-induced DNA fragmentation (apoptosis) in activated T-lymphocytes and Jurkat cells is augmented by inhibition of RNA and protein synthesis. Exp. Hematol. 20: 80-86.

Bissonnette, R.P., F. Echeverri, A. Mahboubi, and D.R. Green. 1992. Apoptotic cell death induced by c-myc is inhibited by bcl-2. Nature 359: 552-554.

Bootsma, D. and J.H. Hoeijmakers. 1993. DNA repair. Engagement with transcription. Nature 363: 114-115.

Caelles, C., A. Helmberg, and M. Karin. 1994. p53-dependent apoptosis in the absence of transcriptional activation of $\mathbf{p} 53$ target genes. Nature 370: 220-223.

Chen, P.L., Y. Chen, R. Bookstein, and W.H. Lee. 1991. Genetic mechanisms of tumor suppression by the human p53 gene. Science 250: 1576-1580.

Cho, Y., S. Gorina, P. Jeffrey, and N.P. Pavletich. 1994. Crystal structure of a p53 tumor suppressor-DNA complex: A framework for understanding how mutations inactivate p53. Science 265: 346-355.

Clarke, A.R., C.A. Purdie, D.J. Harrison, R.G. Morris, C.C. Bird, M.L. Hooper, and A.H. Wyllie. 1993. Thymocyte apoptosis induced by p53-dependent and independent pathways. $\mathrm{Na}$ ture 362: 849-852.

Cleaver, J.E. 1994. It was a very good year for DNA repair. Cell 
76: $1-4$.

Crook, T., N.J. Marston, E.A. Sara, and K.H. Vousden. 1994. Transcriptional activation by p53 correlates with suppression of growth but not transformation. Cell 79: 817-827.

Debbas, M. and E. White. 1993. Wild-type p53 mediates apoptosis by E1A, which is inhibited by E1B. Genes \& Dev. 7: $546-554$

Dittmer, D., S. Pati, G. Zambetti, S. Chu, A.K. Teresky, M. Moore, C. Finlay, and A.J. Levine. 1993. Gain of function mutations in p53. Nature Genet. 4: 42-46.

Drapkin, R., J.T. Reardon, A. Ansari, J.C. Huang, L. Zawel, K. Ahn, A. Sancar, and D. Reinberg. 1994. Dual role of TFIIH in DNA excision repair and in transcription by RNA polymerase II. Nature 368: 769-772.

E1-Deiry, W.S., S.E. Kern, J.A. Pietenpol, K.W. Kinzler, and B. Vogelstein. 1992. Definition of a consensus binding site for p53. Nature Genet. 1: 45-49.

El-Deiry, W.S., T. Tokino, V.E. Velculescu, D.B. Levy, R. Parsons, J.M. Trent, D. Lin, W.E. Mercer, K.W. Kinzler, and B. Vogelstein. 1993. WAF1, a potential mediator of p53 tumor suppression. Cell 75: 817-825.

Enari, M., H. Hug, and S. Nagata. 1995. Involvement of an ICElike protease in Fas-mediated apoptosis. Nature 375: 78-81.

Evan, G.I., A.H. Wyllie, C.S. Gilbert, T.D. Littlewood, H. Land, M. Brooks, C.M. Waters, L.Z. Penn, and D.C. Hancock. 1992. Induction of apoptosis in fibroblasts by c-myc protein. Cell 69: 119-128.

Feaver, W.J., J.Q. Svejstrup, L. Bardwell, A.J. Bardwell, S. Buratowski, K.D. Gulyas, T.F. Donahue, E.C. Friedberg, and R.D. Kornberg. 1993. Dual roles of a multiprotein complex from S. cerevisiae in transcription and DNA repair. Cell 75: 13791387.

Feaver, W.J., J.Q. Svejstrup, N.L. Henry, and R.D. Kornberg. 1994. Relationship of CDK-activating kinase and RNA polymerase II CTD kinase TFIIH/TFIIK. Cell 79: 1103-1109.

Fields, S. and S.K. Jang. 1990. Presence of a potent transcription activating sequence in the p53 protein. Science 249: 10461048.

Flejter, W.L., L.D. McDaniel, D. Johns, E.C. Friedberg, and R.A. Schultz. 1992. Correction of xeroderma pigmentosum complementation group D mutant cell phenotypes by chromosome and gene transfer: Involvement of the human ERCC2 DNA repair gene. Proc. Natl. Acad. Sci. 89: 261-265.

Foord, O.S., P. Bhattacharya, Z. Reich, and V. Rotter. 1991. A DNA binding domain is contained in the C-terminus of wild type p53 protein. Nucleic Acids Res. 19: 5191-5198.

Funk, W.D., D.T. Pak, R.H. Karas, W.E. Wright, and J.W. Shay. 1992. A transcriptionally active DNA-binding site for human p53 protein complexes. Mol. Cell Biol. 12: 2866-2871.

Graeber, T.G., C. Osmanian, T. Jacks, D.E. Housman, C.J. Koch, S.W. Lowe, and A.J. Glaccia. 1996. Hypoxia-mediated selection of cells with diminished apoptotic potential in solid tumours. Nature 379: 88-91.

Greenblatt, M.S., W.P. Bennett, M. Hollstein, and C.C. Harris. 1994. Mutations in the p53 tumor suppressor gene: Clues to cancer etiology and molecular pathogenesis. Cancer Res. 54: 4855-4878.

Harris, C.C., H. Grady, and D. Svoboda. 1968. Alterations in pancreatic and hepatic ultrastructure following acute cycloheximide intoxication. J. Ultrastruct. Res. 22: 240-251.

Haupt, Y., S. Rowan, E. Shaulian, K.H. Vousden, and M. Oren. 1995. Induction of apoptosis in HeLa cells by trans-activation-deficient p53. Genes \& Dev. 9: 2170-2183.

Hermeking, H. and D. Eick. 1994. Mediation of c-Myc-induced apoptosis by p53. Science 265: 2091-2093.

Hollstein, M., D. Sidransky, B. Vogelstein, and C.C. Harris.
1991. p53 mutations in human cancers. Science 253: 49-53.

Hupp, T.R. and D.P. Lane. 1994. Allosteric activation of latent p53 tetramers. Curr. Biol. 4: 865-875.

Hupp, T.R., D.W. Meek, C.A. Midgley, and D.P. Lane. 1992. Regulation of the specific DNA-binding function of p53. Cell 71: 875-886.

Itoh, N., S. Yonehara, A. Ishii, M. Yonehara, S. Mizushima, M. Sameshima, A. Hase, Y. Seto, and S. Nagata. 1991. The polypeptide encoded by the cDNA for human cell surface antigen Fas can mediate apoptosis. Cell 66: 233-243.

Jayaraman, L. and C. Prives. 1995. Activation of p53 sequencespecific DNA binding by short single strands of DNA requires the p53 C-terminus. Cell 81: 1021-1029.

Kastan, M.B., Q. Zhan, W.S. El-Deiry, F. Carrier, T. Jacks, W.V Walsh, B.S. Plunkett, B. Vogelstein, and A.J. Fornace Jr. 1992. A mammalian cell cycle checkpoint pathway utilizing p53 and GADD45 is defective in Ataxia-Telangiectasia. Cell 71: $587-597$.

Kern, S.E., K.W. Kinzler, A. Bruskin, D. Jarosz, P. Friedman, C. Prives, and B. Vogelstein. 1991. Identification of p53 as a sequence-specific DNA-binding protein. Science 252: 17081711.

Kern, S.E., J.A. Pietenpol, S. Thiagalingam, A. Seymour, K.W. Kinzler, and B. Vogelstein. 1992. Oncogenic forms of p53 inhibit p53-regulated gene expression. Science 256: 827830.

Kerr, J.F., A.H. Wyllie, and A.R. Currie. 1972. Apoptosis: A basic biological phenomenon with wide-ranging implications in tissue kinetics. Br. J. Cancer 26: 239-257.

Kraemer, K.H., H.G. Coon, R.A. Petinga, S.F. Barrett, A.E. Rahe, and J.H. Robbins. 1975. Genetic heterogeneity in Xeroderma pigmentosum: Complementation groups and their relationship to DNA repair rates. Proc. Natl. Acad. Sci. 72: 59-63.

Lane, D.P. 1992. Cancer. p53, guardian of the genome. Nature 358: 15-16.

Lee, J.M. and A. Bernstein. 1993. p53 mutations increase resistance to ionizing radiation. Proc. Natl. Acad. Sci. 90: 57425746.

Lee, S., B. Elenbase, A. Levine, and J. Griffith. 1995. p53 and its $14 \mathrm{kDa}$ C-terminal domain recognize primary DNA damage in the form of insertion/deletion mismatches. Cell 81: 1013-1020.

Levine, A.I., I. Momand, and C.A. Finlay. 1991. The p53 tumour suppressor gene. Nature 351: 453-456.

Lin, J., J. Chen, B. Elenbaas, and A.J. Levine. 1994. Several hydrophobic amino acids in the p53 amino-terminal domain are required for transcriptional activation, binding to $\mathrm{mdm}-2$ and the adenovirus $5 \mathrm{ElB} 55 \mathrm{kD}$ protein. Genes \& Dev. 8: $1235-1246$.

Livingstone, L.R., A. White, I. Sprouse, E. Livanos, T. Jacks, and T.D. Tlsty. 1992. Altered cell cycle arrest and gene amplification potential accompany loss of wild-type p53. Cell 70: 923-935.

Los, M., M. Van de Craen, L.C. Penning, H. Schenk, M. Westendorp, P.A. Baeuerle, W. Droge, P.H. Krammer, W. Fiers, and K. Schulze-Osthoff. 1995. Requirement of an ICE/ CED-3 protease for Fas/APO-1-mediated apoptosis. Nature 375: 81-83.

Lowe, S.W. and H.E. Ruley. 1993. Stabilization of the p53 tumor suppressor is induced by adenovirus $5 \mathrm{E} 1 \mathrm{~A}$ and accompanies apoptosis. Genes \& Dev. 7: 535-545.

Lowe, S.W., H.E. Ruley, T. Jacks, and D.E. Housman. 1993a. p53-dependent apoptosis modulates the cytotoxicity of anticancer agents. Cell 74: 957-967.

Lowe, S.W., E.M. Schmitt, S.W. Smith, B.A. Osborne, and T. Jacks. 1993b. p53 is required for radiation-induced apoptosis 
in mouse thymocytes. Nature 362: 847-849.

Lowe, S.W., S. Bodis, A. McClatchey, L. Remington, H.E. Ruley, D.E. Fisher, D.E. Housman, and T. Jacks. 1994. p53 status and the efficacy of cancer therapy in vivo. Science 266: 807810.

Lu, X. and D.P. Lane. 1993. Differential induction of transcriptionally active p53 following UV or ionizing radiation: Defects in chromosome instability syndromes? Cell 75: 765778.

Martin, S.J. 1993. Protein or RNA synthesis inhibition induces apoptosis of mature human CD4 $+\mathrm{T}$ cell blasts. Immunol. Lett. 35: 125-134.

Meek, D.W., S. Simon, U. Kikkawa, and W. Eckhart. 1990. The p53 tumour suppressor protein is phosphorylated at serine 389 by casein kinase II. EMBO 1. 9: 3253-3260.

Miyashita, T. and J.C. Reed. 1995. Tumor suppressor p53 is a direct transcriptional activator of the human bax gene. Cell 80: 293-299.

Miyashita, T., S. Krajewski, M. Krajewska, H.G. Wang, H.K. Lin, D.A. Liebermann, B. Hoffman, and J.C. Reed. 1994. Tumor suppressor p53 is a regulator of bcl-2 and bax gene expression in vitro and in vivo. Oncogene 9: 1799-1805.

Okamoto, K. and D. Beach. 1994. Cyclin G is a transcriptional target of the p53 tumor suppressor protein. EMBO /. 13: $4816-4822$.

Oltvai, Z.N., C.L. Milliman, and S.J. Korsmeyer. 1993. Bcl-2 heterodimerizes in vivo with a conserved homolog, Bax, that accelerates programmed cell death. Cell 74: 609-619.

Owen-Schaub, L.B., W. Zhang, J.C. Cusack, L.S. Angelo, S.M. Santee, T. Fujiwara, J.A. Roth, A.B. Deisseroth, W.W. Zhang, E. Kruzel, and R. Radinsky. 1995. Wild-type human p53 and a temperature-sensitive mutant induce Fas/APO-1 expression. Mol. Cell Biol. 15: 3032-3040.

Perry, M.E., J. Piette, J.A. Zawadzki, D. Harvey, and A.J. Levine. 1993. The $\mathrm{mdm}-2$ gene is induced in response to UV light in a p53-dependent manner. Proc. Natl. Acad. Sci. 90: 1162311627.

Pietenpol, J.A., T. Tokino, S. Thiagalingam, W.S. El-Deiry, K.W. Kinzler, and B. Vogelstein. 1994. Sequence-specific transcriptional activation is essential for growth suppression by p53. Proc. Natl. Acad. Sci. 91: 1998-2002.

Qin, X.Q., D.M. Livingston, W.G. Kaelin, Jr., and P.D. Adams. 1994. Deregulated transcription factor E2F-1 expression leads to S-phase entry and p53-mediated apoptosis. Proc. Natl. Acad. Sci. 91: 10918-10922.

Raff, M.C., B.A. Barres, J.F. Burne, H.S. Coles, Y. Ishizaki, and M.D. Jacobson. 1993. Programmed cell death and the control of cell survival: Lessons from the nervous system. Science 262: 695-700.

Rowan, S., R.L. Ludwig, Y. Haupt, S. Bates, X. Lu, M. Oren, and K.H. Vousden. 1996. Specific loss of apoptotic but not cell cycle arrest function in a human tumour derived p53 mutant. $E M B O$ I. 15: 827-838.

Roy, R., J.P. Adamcsewski, T. Seroz, W. Vermeulen, J.P. Tassan, L. Schaeffer, E.A. Nigg, J.H.J. Hoeijmakers, and J.M. Egly. 1994a. The MO15 cell cycle kinase is associated with the TFIIH transcription-DNA repair factor. Cell 79: 1093-1 101.

Roy, R., L. Schaeffer, S. Humbert, W. Vermeulen, G. Weeda, and J.M. Egly. 1994b. The DNA-dependent ATPase activity associated with the class II basic transcription factor BTF2/ TFIIH. I. Biol. Chem. 269: 9826-9832.

Sabbatini, P., J. Lin, A.J. Levine, and E. White. 1995. Essential role for p53-mediated transcription in ElA-induced apoptosis. Genes \& Dev. 9: 2184-2192.

Schaeffer, L., R. Roy, S. Humbert, V. Moncollin, W. Vermeulen, J.H. Hoeijmakers, P. Chambon, and J.M. Egly. 1993. DNA- repair helicase: A component of BTF2 (TFIIH) basic transcription factor. Science 260: 58-63.

Schaeffer, L., V. Moncollin, R. Roy, A. Staub, M. Mezzina, A. Sarasin, G. Weeda, J.H. Hoeijmakers, and J.M. Egly. 1994. The ERCC2/DNA repair protein is associated with the class II BTF2/TFIIH transcription factor. EMBO /. 13: 2388-2392.

Shaw, P., R. Bovey, S. Tardy, R. Sahli, B. Sordat, and J. Costa. 1992. Induction of apoptosis by wild-type p53 in a human colon tumor-derived cell line. Proc. Natl. Acad. Sci. 89: 4495-4499.

Slingerland, J.M., J.R. Jenkins, and S. Benchimol. 1993. The transforming and suppressor functions of p53 alleles: Effects of mutations that disrupt phosphorylation, oligomerization and nuclear translocation. EMBO I. 12: 1029-1037.

Stefanini, M., P. Lagomarsini, S. Giliani, T. Nardo, E. Botta, A. Peserico, W.J. Kleijer, A.R. Lehmann, and A. Sarasin. 1993. Genetic heterogeneity of the excision repair defect associated with trichothiodystrophy. Carcinogenesis 14: 11011105.

Strasser, A., A.W. Harris, T. Jacks, and S. Cory. 1994. DNA damage can induce apoptosis in proliferating lymphoid cells via p53-independent mechanisms inhibitable by Bcl-2. Cell 79: 329-339.

Sturzbecher, H.W., R. Brain, C. Addison, K. Rudge, M. Remm, M. Grimaldi, E. Keenan, and J.R. Jenkins. 1992. A C-terminal alpha-helix plus basic region motif is the major structural determinant of p53 tetramerization. Oncogene 7:15131523.

Sung, P., V. Bailly, C. Weber, L.H. Thompson, L. Prakash, and S. Prakash. 1993. Human xeroderma pigmentosum group D gene encodes a DNA helicase. Nature 365: 852-855.

Svejstrup, I.Q., Z. Wang, W.J. Feaver, X. Wu, D.A. Bushnell, T.F. Donahue, E.C. Friedberg, and R.D. Kornberg. 1995. Different forms of TFIIH for transcription and DNA repair: HoloTFIIH and a nucleotide excision repairsome. Cell 80: 21-28.

Symonds, H., L. Krall, L. Remington, M. Saenz-Robles, S. Lowe, T. Jacks, and T. Van Dyke. 1994. p53-Dependent apoptosis suppresses tumor growth and progression in vivo. Cell 78: 703-711.

Takenaka, I., F. Morin, B.R. Seizinger, and N. Kley. 1995. Regulation of the sequence-specific DNA-binding function of p53 by protein kinase $\mathrm{C}$ and protein phosphatases. I. Biol. Chem. 270: 5405-5411.

Thut, C.J., J.-L. Chen, R. Klemm, and R. Tiian. 1995. p53 transcriptional activation mediated by coactivators TAFii 40 and TAFii60. Science 267: 100-104.

Vermeulen, W., M. Stefanini, S. Giliani, J.H. Hoeijmakers, and D. Bootsma. 1991. Xeroderma pigmentosum complementation group $\mathrm{H}$ falls into complementation group $\mathrm{D}$. Mutat. Res. 255: 201-208.

Vermeulen, W., R.J. Scott, S. Rodgers, H.J. Muller, J. Cole, C.F. Arlett, W.J. Kleijer, D. Bootsma, J.H. Hoeijmakers, and G. Weeda. 1994a. Clinical heterogeneity within xeroderma pigmentosum associated with mutations in the DNA repair and transcription gene ERCC3. Am. J. Hum. Genet. 54: 191-200.

Vermeulen, W., A.J. van Vuuren, M. Chipoulet, L. Schaeffer, E. Appeldoorn, G. Weeda, N.G.J. Jaspers, A. Priestly, C.F. Arlett, A.R. Lehmann, M. Stefanini, M. Mezzina, A. Sarasin, D. Bootsma, J. Egly, and J.H. Hoeijmakers. 1994b. Three unusual repair deficiencies associated with transcription factor BTF2 (TFIIH): Evidence for the existence of a transcription syndrome. Cold Spring Harbor Symp. Quant. Biol. 58: 317329.

Wagner, A.J., J.M. Kokontis, and N. Hay. 1994. Myc-mediated apoptosis requires wild-type p53 in a manner independent of cell cycle arrest and the ability of $\mathrm{p} 53$ to induce p21waf1/ 
cipl. Genes \& Dev. 8: 2817-2830.

Wang, L., M. Miura, L. Bergeron, H. Zhu, and J. Yuan. 1994. Ich-1, an Ice/ced-3-related gene, encodes both positive and negative regulators of programmed cell death. Cell 78: 739750.

Wang, X.W., K. Forrester, H. Yeh, M.A. Feitelson, J.R. Gu, and C.C. Harris. 1994. Hepatitis B virus X protein inhibits p53 sequence-specific DNA binding, transcriptional activity, and association with transcription factor ERCC3. Proc. Natl. Acad. Sci. 91: 2230-2234.

Wang, X.W., M.K. Gibson, W. Vermeulen, H. Yeh, K. Forrester, H.W. Sturzbecher, J.H.J. Hoeijmakers, and C.C. Harris. 1995a. Abrogation of p53-induced apoptosis by the hepatitis B virus X gene. Cancer Res. 55: 6012-6016.

Wang, X.W., H. Yeh, L. Schaeffer, R. Roy, V. Moncollin, J.M. Egly, Z. Wang, E.C. Friedberg, M.K. Evans, B.G. Taffe, V.A. Bohr, J.H. Hoeijmakers, K. Forrester, and C.C. Harris. 1995b. p53 Modulation of TFIIH-associated nucleotide excision repair activity. Nature Genet. 10: 188-195.

Wang, Z., J.Q. Svejstrup, W.J. Feaver, X. Wu, R.D. Kornberg, and E.C. Friedberg. 1994. Transcription factor b (TFIIH) is required during nucleotide-excision repair in yeast. Nature 368: 74-76.

Weeda, G., R.C. van Ham, W. Vermeulen, D. Bootsma, A.J. van der Eb, and J.H. Hoeijmakers. 1990. A presumed DNA helicase encoded by ERCC-3 is involved in the human repair disorders xeroderma pigmentosum and Cockayne's syndrome. Cell 62: 777-791

Wolkowicz, R., A. Peled, N.B. Elkind, and V. Rotter. 1995. Augmented DNA-binding activity of p53 protein encoded by a carboxyl-terminal alternatively spliced mRNA is blocked by p53 protein encoded by the regularly spliced form. Proc. Natl. Acad. Sci. 92: 6842-6846.

Wu, X. and A.J. Levine. 1994. p53 and E2F-1 cooperate to mediate apoptosis. Proc. Natl. Acad. Sci. 91: 3602-3606.

Xiao, H., A. Pearson, B. Coulombe, R. Truant, S. Zhang, J.L. Regier, S.J. Triezenberg, D. Reinberg, O. Flores, C.J. Ingles, et al. 1994. Binding of basal transcription factor TFIIH to the acidic activation domains of VP16 and p53. Mol. Cell Biol. 14: 7013-7024.

Yin, Y., M.A. Tainsky, F.Z. Bischoff, L.C. Strong, and G.M. Wahl. 1992. Wild-type p53 restores cell cycle control and inhibits gene amplification in cells with mutant p53 alleles. Cell 70: 937-948.

Yonish-Rouach, E., D. Resnitzky, J. Lotem, L. Sachs, A. Kimchi, and M. Oren. 1991. Wild-type p53 induces apoptosis of myeloid leukaemic cells that is inhibited by interleukin-6. $\mathrm{Na}$ ture 352: 345-347.

Zhan, Q., K.A. Lord, I. Alamo, Jr., M.C. Hollander, F. Carrier, D. Ron, K.W. Kohn, B. Hoffman, D.A. Liebermann, and A.J. Fornace, Jr.. 1994. The GADD and MyD genes define a novel set of mammalian genes encoding acidic proteins that synergistically suppress cell growth. Mol. Cell Biol. 14: 23612371 . 


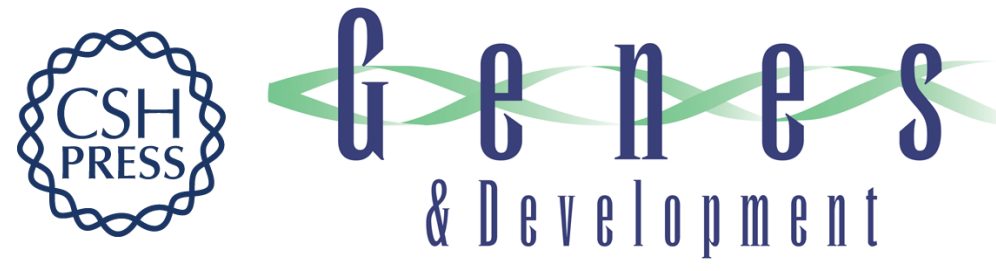

\section{The XPB and XPD DNA helicases are components of the p53-mediated apoptosis pathway.}

X W Wang, W Vermeulen, J D Coursen, et al.

Genes Dev. 1996, 10:

Access the most recent version at doi:10.1101/gad.10.10.1219

References This article cites 96 articles, 35 of which can be accessed free at:

http://genesdev.cshlp.org/content/10/10/1219.full.html\#ref-list-1

License

Email Alerting

Service

Receive free email alerts when new articles cite this article - sign up in the box at the top right corner of the article or click here.

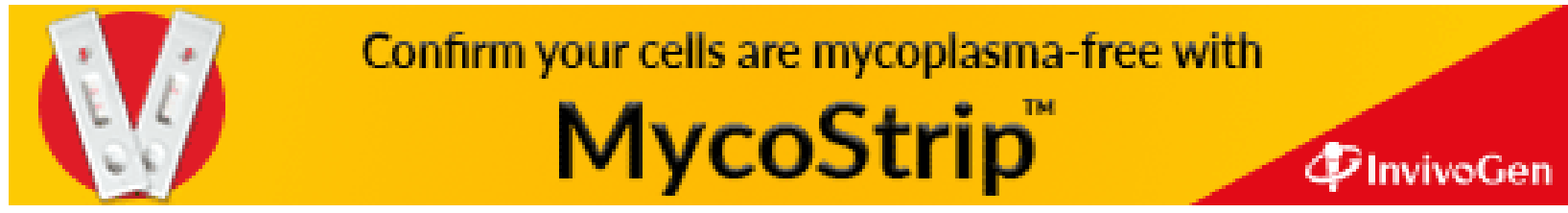

